DOI: 10.17707/AgricultForest.64.4.16

\author{
Nemanja GRŠIĆ*, Jelena B. POPOVIĆ-円ORĐEVIĆ, \\ Aleksandar Ž. KOSTIĆ, Biljana DOJČINOVIĆ, and Nebojša Đ. PANTELIĆ
}

\title{
ALKALI AND ALKALINE EARTH METALS IN WATER - CASE STUDY OF THE BOJANA RIVER, MONTENEGRO
}

\section{SUMMARY}

1) Background: Water is one of the most important natural resources as it is widely used in households, agriculture, industry and tourism. Therefore water conservation should be a basic human need. The goal of this investigation was to determine the content of alkali ( $\mathrm{Na}, \mathrm{K})$ and alkaline earth metals $(\mathrm{Mg}, \mathrm{Ca}, \mathrm{Ba}, \mathrm{Sr}$ ) in real water samples from the Bojana River, Montenegro;

2) Methods: Samples were collected two locations: L1 - where Bojana River forms a small delta, and $\mathbf{L} \mathbf{2}$ - where it flows into the Adriatic Sea, and tested in August 2017. The contents of metals in samples were determined by inductively coupled plasma with optical emission spectrometry (ICP-OES);

3) Results: The concentrations of alkali and alkaline earth elements were higher in the sample $\mathbf{L} 2$ when compared to the sample L1. Statistically significant differences were observed for contents of $N$ a and $K(\mathrm{p}<0.01)$ as well as for $\mathrm{Mg}, \mathrm{Sr}$ and $\mathrm{Ba}(\mathrm{p}<0.05)$. As all alkali metal salts are well dissolved in water and due to the presence of a large amount of minerals in the sea, the obtained results for $\mathbf{L} 2$ sample were expected. Due to the high popularity of tourist island - Ada Bojana, the preservation of the quality of the Bojana River is prerequisite.

Keywords: alkali metals; alkaline earth metals; ICP-OES analysis; the Bojana River; Montenegro

\section{INTRODUCTION}

Water is one of the most important natural resources. It is an essential substance for life and also is considered as a universal solvent capable of dissolving almost all solutes. Additionally, water is widely used in households, agriculture, industry and tourism, and therefore water conservation should be a basic human need. The chemical characteristics of natural waters are the reflection of the soils and rocks which have been in contact with water (Pantelić et al. 2017).

\footnotetext{
${ }^{1}$ Nemanja Gršić *(corresponding author: nemanja.grsic@agrif.bg.ac.rs), University of Belgrade, Faculty of Agriculture, Department of Agroecology and Agritechnic, Belgrade, SERBIA; Jelena B. Popović-Đorđević, Aleksandar Ž. Kostić and Nebojša Đ. Pantelić, University of Belgrade, Faculty of Agriculture, Department of Chemistry and Biochemistry, Belgrade, SERBIA; Biljana Dojčinović, University of Belgrade, Institute of Chemistry, Technology and Metallurgy, Belgrade, SERBIA;

Paper is presented on Green Room Sessions - International Conference, Podgorica 2018

Notes: The authors declare that they have no conflicts of interest. Authorship Form signed online.
} 
Skadar Lake catchment area represents one of the richest freshwater areas in the World due to the specific natural factors (Radulović et al., 2015). The Bojana River arises from Lake Skadar and it is about $40 \mathrm{~km}$ long (Petković and Sekulić, 2015). The total outflow of water from the lake through the Bojana River is nearly $304 \mathrm{~m}^{3} / \mathrm{s}$. After the Nile and the Po, the Bojana River is the third river on the Mediterranean by its water amount brought into the sea. The most distinctive feature of the Bojana River is that the bottom of its riverbed is under the sea level in the length of $36 \mathrm{~km}$. At some places the bottom of the riverbed is between two and five meters under the sea level. In its riverbed there is both salty sea water and fresh river water. Although the Bojana River has a big flow, sea water rushes deeply upwards at the bottom of the riverbed, due to the fact that sea water is of higher density. Also, today there are two river flows with the same direction, aiming towards the sea; one is a surface water flow, while the other is about 10 to 15 meters below the ground water flow which contributes to the peculiarity of the Bojana River. Approaching the sea, the river splits into two sleeves which then separately flow into the Adriatic Sea close to the town of Ulcinj. The Bojana River Delta is a unique ecosystem in Europe. As a result of the deposition of sediment carried by the Bojana River to the Adriatic Sea, after the Drim River altered course to flow into the Bojana River, Ada Bojana island was created. This island, with about $5 \mathrm{~km}^{2}$ of surface area, is situated in the Bojana River Delta, and now is one of the most important tourist resources of Montenegro (Petković and Sekulić, 2015).

The quality and quantity of the chemical elements in surface waters is affected by geo-chemical structure of surrounding area, land use, seasonal variations of weather conditions, vegetation and the atmospheric deposit (Potasznik and Szymczyk, 2015). By the extensive search of the literature no data on the chemical composition of the Bojana River was found.

In that respect, the aim of this study was to determine the content of alkali $(\mathrm{Na}, \mathrm{K})$ and alkaline earth metals $(\mathrm{Mg}, \mathrm{Ca}, \mathrm{Ba}, \mathrm{Sr})$ in real water samples from the Bojana River, Montenegro.

\section{MATERIAL AND METHODS}

Water samples from the Bojana River, Montenegro, were taken at two locations; where Bojana River forms a small delta (L1), and - where it flows into the Adriatic Sea (L2), Figure 1. Samples were collected and tested in August 2017. The contents of metals ( $\mathrm{Na}, \mathrm{K}, \mathrm{Mg}, \mathrm{Ca}, \mathrm{Sr}$ and $\mathrm{Ba}$ ) in samples were determined by inductively coupled plasma with optical emission spectrometry (ICP-OES) as described in our previous work (Kostic et al. 2016).

For the analysis samples were collected in the glass flasks of $1 \mathrm{~L}$ which were previously washed with $\mathrm{HNO}_{3}(1: 1, \mathrm{v} / \mathrm{v})$ and then thoroughly rinsed with ultra-pure water. For the purposes of element stabilization and reduction of the adsorption of metals on the glass surface, $1 \mathrm{~mL}$ of $65 \%$ nitric acid was added on $1 \mathrm{dm}^{3}$ of water. The samples were stored in the refrigerator. The digestion was 
performed on the Advanced Microwave Digestion System (ETHOS 1, Milestone, Italy) using HPR-1000/10S high pressure segmented rotor. ICP-OES analysis was performed using Thermo Scientific iCAP 6500 Duo ICP (Thermo Fisher Scientific, Cambridge, United Kingdom) spectrometer equipped with RACID86 Charge Injector Device (CID) detector, concentric type nebulizer, quartz torch and alumina injector. EPA Method 200.7 was applied (Cassap, 2010).

Total Hardness (TH) was calculated as described in Milojković et al. (2018):

$\mathrm{TH} \approx[\mathrm{Ca}]+[\mathrm{Mg}]$

$\mathrm{TH}$ in ${ }^{\circ} \mathrm{d}=0.1339 \times[\mathrm{Ca}$ in $\mathrm{mg} / \mathrm{L}]+0.2307 \times[\mathrm{Mg}$ in $\mathrm{mg} / \mathrm{L}]$

The results of the study are the averages of triplicate measurements and are presented as means value and standard deviation (SD). The results obtained during the study were analyzed statistically, by the method of analysis of variance ( $F$ test) for single-factorial trials, and the significance of the differences between treatments was also tested by the LSD test at the same levels of significance (Stanković et al. 1989).

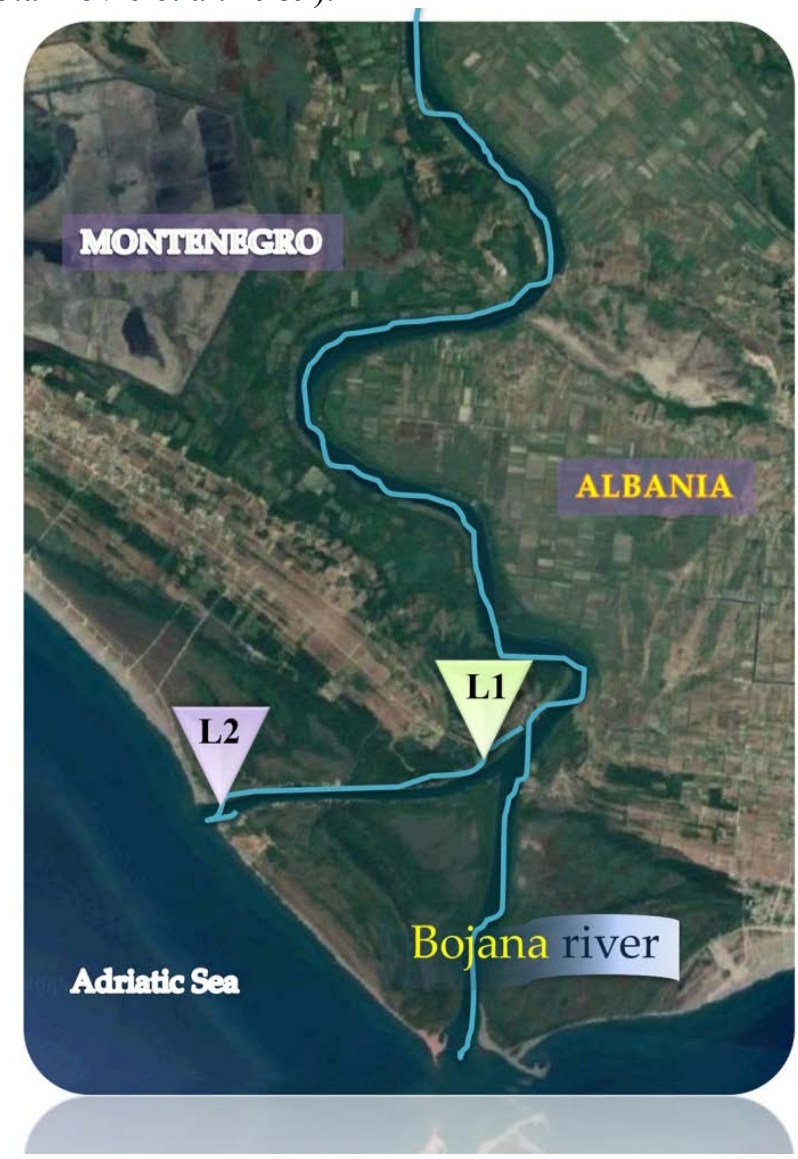

Figure 1. Study area 


\section{RESULTS AND DISCUSSION}

Water from the Bojana River was studied at two locations; one where it forms a small delta, and another one in the vicinity of tourist island - Ada Bojana where the river flows into the Adriatic Sea the obtained results are compared.

Elements that are dominant in water are alkali and alkaline earth metals ( $\mathrm{Li}, \mathrm{Na}, \mathrm{K}, \mathrm{Mg}, \mathrm{Ca}, \mathrm{Ba}, \mathrm{Sr}$ ). Their presence in the water is mainly attributed to natural processes (Kostić et al. 2016). Table 1 presents a literature overview of the contents of selected alkali and alkaline earth metals in different water sources.

Table 1. Content of selected alkali and alkaline earth metals (mg/L) in natural fresh waters

\begin{tabular}{|c|c|c|c|c|c|c|}
\hline $\mathrm{Na}$ & $\boldsymbol{K}$ & $M g$ & $\mathrm{Ca}$ & $\mathrm{Sr}$ & $B a$ & Water source \\
\hline 1.4 & 1.2 & 7.2 & 40.7 & & & $\begin{array}{l}\text { The Reine River (Alps, } \\
\text { Swiss) }^{1}\end{array}$ \\
\hline 14.6 & 2.9 & 19.7 & 60.6 & 0.26 & 0.036 & The Dunav River, Serbia ${ }^{2}$ \\
\hline \multirow[t]{2}{*}{ 3.3-4.3 } & $0.9-1.8$ & $4.3-7.2$ & $25-62.5$ & & & The Božićka river, Serbia ${ }^{3}$ \\
\hline & & 10.9 & 56.1 & & & $\begin{array}{l}\text { The Symsarna River, } \\
\text { Poland }^{4}\end{array}$ \\
\hline \multirow[t]{2}{*}{19.6} & 1.2 & 26.6 & 81.96 & 0.24 & 0.075 & Well water ${ }^{2}$ \\
\hline & & & & $\begin{array}{l}0.002-0.23 \\
8\end{array}$ & $0.004-0.073$ & River water ${ }^{5}$ \\
\hline 10500 & 380 & 1350 & 400 & 8.00 & $0.002-0.015$ & Sea/Ocean water ${ }^{\mathbf{1 , 5}}$ \\
\hline
\end{tabular}

${ }^{1}$ http://www.waterencyclopedia.com/En-Ge/Fresh-Water-Natural-Composition-of.html;

${ }^{2}$ Kostić et al. 2016; ${ }^{3}$ Presburger Ulniković et al. 2016; ${ }^{4}$ Potasznik and Szymczyk, 2015; ${ }^{5}$ KabataPendias and Szteke, 2015.

Concentrations of $N a$ and $K$ are nearly equal in the Earth's crust, but in natural waters $\mathrm{Na}$ is far more abundant compared to $K$, especially in sea water (Table 1). Potassium is an important element for aquatic animal and plant species, although the least abundant of four major elements $(\mathrm{Ca}>\mathrm{Mg}>\mathrm{Na}>\mathrm{K})$ in natural waters. Nevertheless, the order of concentrations of major elements in average sea water is quite different, $N a>M g>C a \approx K$. It is reported in the literature that presence of $K$ ions in some lake water is positively related to biological productivity (Talling, 2010).

In this study, $\mathrm{Na}$ and $\mathrm{Ba}$ were measured in the highest and lowest concentrations; $1182.00 / 0.011 \mathrm{mg} / \mathrm{L}$ in $\mathbf{L} 2$ and L1, respectively (Figure 2). In general concentrations of $\mathrm{Na}$ and $\mathrm{K}$ in studied samples were much higher than reported in literature for river water (Table 1 ). Their content was significantly different between the samples $(p<0.01)$, and higher concentrations of both elements were recorded in the sample $\mathbf{L} 2$ originated from the location in the vicinity of Ada Bojana island (Figure 2, Table 1). As all alkali metal salts are 
well dissolved in water and due to the presence of a large amount of minerals in the sea, the obtained values in $\mathbf{L} \mathbf{2}$ sample could be expected.

Magnesium and calcium are naturally found in surface waters (Table 1), and they are the most widely available alkaline earth metals in the environment. Sedimentary rocks, usually limestone and chalk are the most common sources of $\mathrm{Ca}$ and $\mathrm{Mg}$ (WHO, 2011). Magnesium salts could be found naturally in high concentrations in surface and underground waters. The only other elements that occur on a larger scale are $\mathrm{Na}$ and $\mathrm{Ca}$. Calcium compounds occur naturally in surface water, and their concentrations are mainly determined by the carbonate balance (Potasznik and Szymczyk, 2015).

Concentrations of $\mathrm{Mg}$ and $\mathrm{Ca}$ were higher in the sample $\mathbf{L 2}$ (Figure 2), taken on the location where the Bojana River flows into the Adriatic Sea. Statistically significant difference between samples was observed only for the content of $M g(p<0.05)$. Having in mind that $C a$ and $M g$ are important nutrients for aquatic plants, the most effective $\mathrm{Ca} / \mathrm{Mg}$ ratio should be 3:1 to 4:1 (Potasznik and Szymczyk, 2015). In the studied samples the ratio of $\mathrm{Ca} / \mathrm{Mg}$ was much lower; 0.73:1 and 0.69:1 for $\mathbf{L} \mathbf{1}$ and $\mathbf{L 2}$, respectively. Such ratios were attribute to higher concentrations of $\mathrm{Mg}$ in both water samples, $81.59 \mathrm{mg} / \mathrm{L}(\mathbf{L 1})$ and 106.90 (L2) mg/L compared to concentrations of Ca, $59.54 \mathrm{mg} / \mathrm{L}(\mathbf{L 1})$ and 73.72 $\mathrm{mg} / \mathrm{L}$ (L2), which is specific for sea water (see Table 1 ).
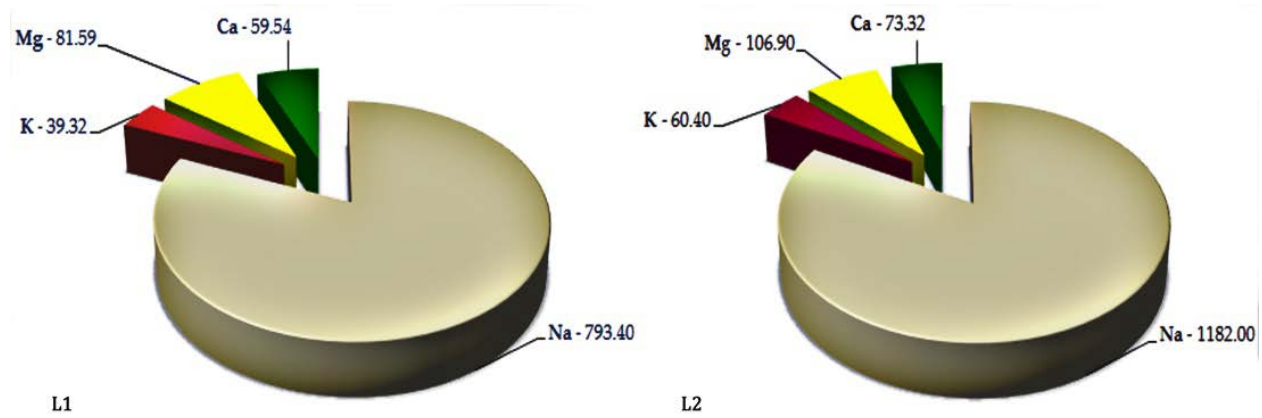

Figure 2. The content of major elements (mg/L) in water samples $\mathbf{L} \mathbf{1}$ and $\mathbf{L} \mathbf{2}$

Total hardness is usually defined as the molar concentrations of all multivalent cations in water with the exception of the monovalent cations. Calcium and magnesium are predominant cations, although other cations such as aluminum, barium, iron, manganese, strontium, and zinc also contribute. Nevertheless, in practice, the sum of two major fresh-water cations ( $\mathrm{Ca}$ and $\mathrm{Mg}$ ) usually determines TH (WHO, 2009).

In addition to performed analyses, total hardness $(\mathrm{TH})$ of the Bojana River water was calculated based on the $C a$ and $M g$ concentrations. In samples $\mathbf{L 1}$ and L2, TH expressed as German hardness degrees $\left(\mathrm{d}^{\circ}\right)$, was 26.79 and 35.53, 
respectively. The dissolved polyvalent metallic ions from sediments, leakage and swelling from the ground could be the main natural sources of hardness in water.
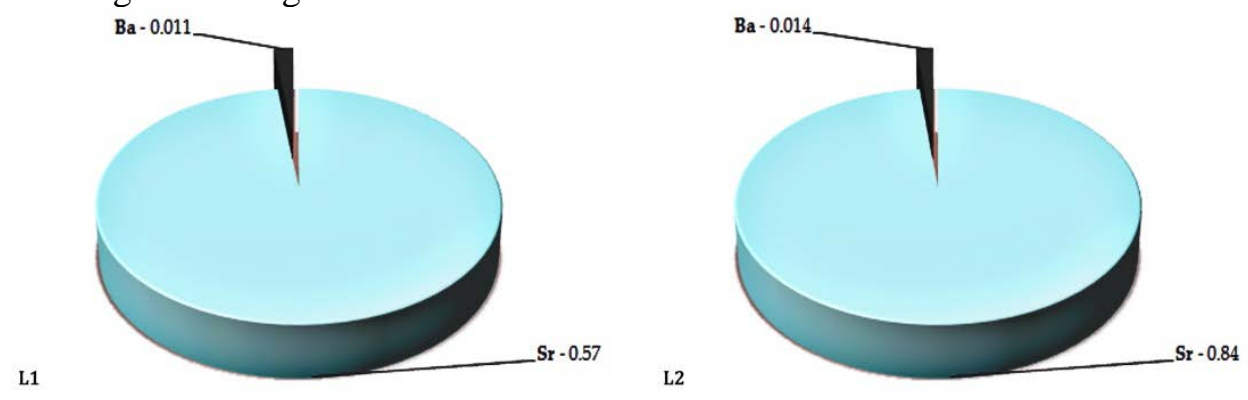

Figure 3. The content of $S r$ and $B a(\mathrm{mg} / \mathrm{L})$ in water samples $\mathbf{L 1}$ and $\mathbf{L 2}$

The results obtained for $\mathrm{Sr}$ and $\mathrm{Ba}$ are shown in Figure 3. As expected, these elements were detected in the lowest concentrations in both samples; 0.57/0.84 mg/L of $S r$ and 0.011/0.014 mg/L of $B a$ in $\mathbf{L} 1$ and $\mathbf{L 2}$, respectively. According to surface water regulations of Environmental Protection Agency (EPA, 2001) imperative values for $B a$ are in the range of $0.10-1.0 \mathrm{mg} / \mathrm{L}$. Results obtained in this study indicated much lower concentrations of $\mathrm{Ba}$ in both samples. On the other hand, results in this study for $\mathrm{Sr}$ were higher, whilst results for $B a$ were in the line with literature data for river water presented in Table 1 (Kabata-Pendias and Szteke, 2015).

Statistical analysis of results indicated significant differences between samples for contents of $N$ a and $K(p<0.01)$ as well as for $M g$, $S r$ and $B a(p<0.05)$. Concentrations of $\mathrm{Ca}$ were not significantly different between samples (Table 2).

Table 2. Statistical analysis of elements content in water samples

\begin{tabular}{llll}
\hline & \multirow{2}{*}{$\mathrm{F}$} & \multicolumn{2}{c}{ LSD } \\
\cline { 3 - 4 } & & 0.05 & 0.01 \\
\hline $\mathrm{Na}$ & $431,654^{* *}$ & 80,477 & 185,634 \\
$\mathrm{~K}$ & $128,129^{* *}$ & 8,013 & 18,483 \\
$\mathrm{Mg}$ & $26,901^{*}$ & 20,996 & 48,432 \\
$\mathrm{Ca}$ & 13,903 & 15,901 & 36,679 \\
$\mathrm{Sr}$ & $57,957^{*}$ & 0,151 & 0,349 \\
$\mathrm{Ba}$ & $23,822^{*}$ & 0,003 & 0,007 \\
\hline
\end{tabular}

*Statistically significant difference ${ }^{*}-p<0.05$ and ${ }^{* *}-p<0.01$.

\section{CONCLUSIONS}

Results have shown that the concentrations of alkali metals ( $N a$ and $K$ ) and alkaline earth elements $(\mathrm{Mg}, \mathrm{Ca}, \mathrm{Sr}$ and $\mathrm{Ba}$ ) were significantly higher in water sample originated from the location where the Bojana River flows into the Adriatic Sea (near Ada Bojana island). In both samples concentrations of elements were in the following order: $\mathrm{Na}>\mathrm{Mg}>\mathrm{Ca}>\mathrm{K}>\mathrm{Sr}>\mathrm{Ba}$ which is, especially in the case of major elements, characteristic of sea water. These chemical 
composition characteristics are more pronounced in the sample taken on the location where the Bojana River immerse into the Adriatic Sea, as the water from the sea flows back to the river.

The chemical composition of studied samples showed that water has specific characteristics and confirms the duality of the Bojana River water, due to the fact that its riverbed is a few meters under the sea level. Indeed, with all its characteristics the Bojana river represents a natural phenomenon.

\section{ACKNOWLEDGMENTS}

This work was supported by the Ministry of Education, Science and Technological Development of the Republic of Serbia (Grant Nos. 46009 and 172035). Authors are thankful to D. Popović - Beogračić for help in the design and graphic processing of images.

\section{REFERENCES}

Aquion (2016) [WWW Document]. URL www.aqion.de/site/140

Cassap, M. (2010): Using ICP-OES for accurate monitoring of metallic contaminants in water according to U.S. EPA Method 200.7. Spectroscopy-US 25(5): 64-69.

Hardness in drinking-water (2011): Background document for development of WHO guidelines for drinking -water quality, WHO (available at https://www.who.int/ water sanitation health/dwq/ chemicals/ hardness . pdf).

http://www.waterencyclopedia.com/En-Ge/Fresh-Water-Natural-Composition-of.html (accessed on October 2018)

Kabata-Pendias A. \& Szteke B. (2015): Trace Elements in Abiotic and Biotic Enviroments, CRC Press, Taylor \& Francis Group, Boca Raton, FL.

Kostić, A.Ž., Pantelić, N.Đ, Jonaš, J.P., Kaluđerović, L.M., Dojčinović, B.P. \& PopovićDjordjević, J.B. (2016): Physicochemical properties of waters from southern Banat (Serbia); potential leaching of some trace elements from ground and human health risk. Expos Health, 8(2): 227-238.

Milojković, J.V., Popović-Đorđević, J.B., Pezo, L.L., Brčeski, I.D., Kostić, A.Ž., Milošević, V. \& Stojanović, M.D. (2018): Applying multi-criteria analysis for preliminary assessment of the properties of alginate immobilized Myriophyllum spicatum in lake water, Water Res. 141:163-171.

Pantelić, N., Dramićanin, A.M., Milovanović, D.B., Popović-Đorđević, J.B. \& Kostić, A.Ž. (2017): Evaluation of the quality of drinking water in Rasina district, Serbia: physicochemical and bacteriological viewpoint, Rom. J. Physics. 62, No. 818.

Parameters of water quality: interpretation and standards (2001): Environmental Protection Agency, Ireland

Petković, S. \& Sekulić, G. (2018): Erosion and sedimentation processes in the Bojana River Delta at the Adriatic Sea, J. Costal Conserv. https://doi.org/10.1007/s11852018-0634-9

Potasznik A. \& Szymczyk S. (2015): Magnesium and calcium concentrations in the surface water and bottom deposits of a river-lake system. J. Elem. 20(3):677-692.

Presburger Ulniković, V., Polavder, S., Cibulić, V., Mrazovac Kurilić S. \& Adamović, V. (2016): Kvalitet površinskih voda u okolini fosforitnog ležišta "Lisina", 
Bosilegrad, Water 2016: Conference Proceedings 45th Annual Conference of the Serbian Water Pollution Control Society, Zlatibor 15-17 June 2016.

Radulovic, M., Radulovic, M., Stevanovic, Z., Sekulic, G., Radulovic, V., Buric, M., Novakovic, D., Vako, E., Blagojevic, M., Devic, N. \& Radojevic, D. (2015): Hydrogeology of the Skadar Lake basin (Southeast Dinarides) with an assessment of considerable subterranean inflow. Environ. Earth Sci. 74, 71-78.

Stanković, J., Ralević, N. R. \& Ljubanović-Ralević I. (1989): Statistika sa primenom u poljoprivredi, Savremena administracija, Beograd.

Talling, J.F. (2010): Potassium- a non-limiting nutrient in fresh waters? Freshw. Rev. 3, 97-104.

World Health Organization (2009): Calcium and magnesium in drinking water: public health significance. Geneva: World Health Organization. (available at http://www.who.int/iris/handle/10665/43836) 